\title{
中心性䅡髄損傷急性期の治療成績
}

\section{Treatment Outcome of Acute Central Cervical Cord Injury}

\author{
安斉公雄中村博彦
}

Kimio Anzai, M. D., Hirohiko Nakamura, M. D.

\begin{abstract}
Objective : Central cord syndrome is the more common incomplete type of spinal cord injury in patients of middle and older age associated with hyper-extention of the cervical spine. We summarized the treatment outcome of patients with central cervical cord injury (CCCI) and evaluated recovery of neurological function.

Methods : Sixty-one patients of $\mathrm{CCCl}$ were treated. The clinical characteristics including age, gender, cause and mechanism of trauma, neurological symptoms, treatment were retrospectively obtained from medical records and statistically analyzed as prognostic factors for better outcome. Patients received thirty-one of 61 steroids as the NASCIS- II protocol just after admission. Seventeen patients were treated surgically. NCSS (Neurological Cervical Spine Scale) was used for the evaluation of neurological symptoms and singns estimation of the rate of recovery.

Results : Male were 43 cases and female were 18, averaged age was 60.1 years (ranged 2586 years, median age was 63 years). Improvement was obtained in all cases but complete resolution of neurological deficit was obtained in only 2 of 61 . The average rate of recovery in NCSS scoring was $59.1 \%$. Neurological signs and recovery of lower extremities were statistically better than those of upper extremities. Treatment-related death was not experienced. The clinical characteristics of patients were statistically analyzed, males demonstrated better outcome than femals and the group of traffic accident better than that of falling patients group. The averaged rate of recovery was not statistically different between medical and surgical treatment groups, $59.6 \%$ and $57.6 \%$. The duration from onset of trauma to the surgical treatment was not influencing for the outcome.

Conclusion: Treatment outcome in patients with $\mathrm{CCCl}$ was having acceptable resnlts, but complete resolution of neurological signs was difficult. Neurological symptoms and recovery of upper extremities were worse than that of lower extremities. Surgical treatment for $\mathrm{CCCl}$ could improve the outcome even on the conservative treatment group.
\end{abstract}

(Received : August 17, 2009 ; accepted : December 4, 2009)

\section{Key words}

cervical cord injury, central cord syndrome, surgical decompression

\section{はじめに}

中心性頚髄損傷は不完全䅡髄損傷のなかで最も多く認 められ，そのほとんどが頚椎の過伸展により生じ，下肢 に比べて上肢，特に手の機能障害が強く認められる．予 後は比較的良好であるといわれているものの，手指の巧
緻運動障害，しびれ，感覚低下などが残存し，治療後の 患者の満足度はそれほど高くない場合も少なくはない. 保存的に治療されることが多く，外科治療の適応の決定 に関しては一定の見解は得られていない.今回，われわ れの施設にて初期治療が行われた中心性澒髄損傷例に対 する治療成績を評価し，神経症状の改善，治療方法，手

中村記念病院脳神経外科 $/$ T060-8570 札幌市中央区南 1 条西 14 丁目〔連絡先 : 安斉公雄〕

Address reprint requests to : Kimio Anzai, M. D., Department of Neurosurgery, Nakamura Memorial Hospital, South 1, West 14, Chuo-ku, Sapporo-shi, Hokkaido 060-8570, Japan 
術時期による影響，予後に関係する因子などについての 検討を加え，本症に対する外科治療の位置づけなどにつ いて考察を加えた。

\section{対象および方法}

1997 年 2 月 2008 年 10 月に当院にて初期治療が行 われた中心性澒髄損傷 61 例が今回の対象である. Neurological cervical spine scale（NCSS）を使用して神経症 状を評価し, 入院時, 退院時の総点数から神経症状の改 善率を算出〔改善率 $=$ (退院時の総点数一入院時の総点 数 $) /$ (最高点数 $(14)$-入院時の総点数 $) \times 100$ した. 上 下肢別の運動機能の改善, 各要因 (年齢, 性別, 受傷原 因, 損傷機序, 原因疾患) 別の平均改善率の比較, 入院 時における神経症状の重症度, MRI での T2 強調像にお ける髄内の高信号所見の有無, MRI もしくは CT（軸位 像）に㧍ける脊髄の变形の程度（脊髄変形率）などを評 価し，治療予後への影響を検討した。また治療方法別 (ステロイドの大量持続静注療法の施行, 保存治療, 外科 治療の追加など）の治療成績の比較に加え，外科治療の 施行時期が治療成績に与える影響などについても検討し た. 統計処理に関しては, 単変量解析として Student の $t$ 検定, ANOVA を, 多变量解析として重回帰分析を使用 し, $\mathrm{p}<0.05$ にて統計学的に有意とした.

\section{患者背景}

男性は 43 例, 女性は 18 例で平均年齢は 60.1 歳 (25〜 86 歳, 中央值 63 歳) であった。受傷原因に関しては, 転倒が 35 例と最多で, 以下, 転落 (11 例), 交通事故 (10 例), スポーツでの受傷 (3 例), その他 (2 例) で あった。損傷機序に関しては, 過伸展損傷が 39 例と約 3 分の 2 を占め, 過屈曲損傷は 10 例, 不明が 12 例で あった。原因疾患は脊柱管狭窄症が 38 例と最多で, 以 下, 椎間板へルニア (14 例), 後縦勒带骨化症 (6 例), 頚椎症 (2 例), 頚椎骨折（1 例）と続いた. 31 例では入 院直後より NASCIS-IIに準じたステロイド (ソル・メド ロール)の大量持続静注療法が施行された。 44 例では保 存治療 (澒部外固定, 安静, 点滴, 投薬, リハビリテー ションなど）にて退院されたが, 17 例では外科治療の追 加を要した。平均入院期間は 7.4 週間（1２6 週間, 中 央值は 6 週間）であった。

\section{結 果}

61 例全例においてなんらかの神経症状の改善が得ら れ, NCSS での平均改善率は $59.1 \%(22.2 \sim 100 \%)$ であっ たが，神経症状が完全に消失した例（NCSS 改善率 $100 \%$ ）は 2 例（3.3\%）にすぎず，退院時点ではほとん どの症例でなんらかの障害が残存した，合併症を含めた 入院中の死亡例は認められなかった。

上下肢別の機能障害に関して, 入院時の運動機能の重 症度を NCSS の運動機能スコア（5 点満点）を用いて比 較すると，上肢に扔ける平均スコアは 2.13 で，下肢に㧈 ける平均スコアの 3.48 よも有意に上肢の運動機能の 障害の程度が強かった $(\mathrm{p}<0.0001)$ ，退院時の平均スコ アは上肢 3.84 , 下肢 4.61 とその傾向は同様であった（p $<0.0001)$. 改善率の平均值を比較すると上肢では $59.4 \%$ で，下肢の $74.8 \%$ と比較すると，有意に上肢での運動機 能の改善率が低い $(\mathrm{p}=0.0043)$ こど証明された.

年齢に関しては 60 歳代に多い一峰性の分布を認めた (Fig. 1). 各症例に扮ける年齢と NCSS 改善率における 相関を調べてみたが，一定の相関関係は認められなかっ た(Fig. 2).

性別に関しては, 男性（43 例）での平均改善率は $62.0 \%$, 女性（18 例）での平均改善率は $52.0 \%$ と男性の 治療成績が有意に良好であった $(\mathrm{p}=0.0354)$ が，その理 由は定かではない.

受傷原因別の平均改善率は, 転倒群（35 例） 58.6\%, 転落群（11 例） $46.2 \%$ ，交通事故群（10 例） $71.0 \%$ ， ス ポーツでの受傷群（3 例） $61.0 \%$ あ゙あた。各群間での 改善率を比較してみたところ, 転落群と交通事故群間の みにおいて有意な差を認めた。

損傷機序別の平均改善率の比較では, 過伸展群 (39 例) での $60.3 \%$ と過屈曲群 $(10$ 例 $)$ での $61.0 \%$ の間に有意な 差は認められなかった。

原因疾患別の平均改善率の比較では, 脊柱管狭窄症 （38 例） 56.5\%，椎間板へルニア（14 例）63.8\%，後縦 勒帯骨化症（6 例） $65.1 \%$ で, 各群間にて有意な差は認 められなかった。

入院時に扔ける神経症状の重症度では, NCSSにて上 下肢の運動機能, 知覚障害すべてで高度障害を呈した場 合の総点数である 5 点を境界として，5 点以下の重症群 (14 例) と 6 点以上の非重症群（47 例）に分けたが, 平 均改善率の比較では重症群での $57.4 \%$, 非重症群での $59.6 \%$ の間に有意な差は認められなかった。

MRI での T2 強調像における髄内の高信号所見の有無 に関しては，38 例にて所見を認め，23 例では所見を認 


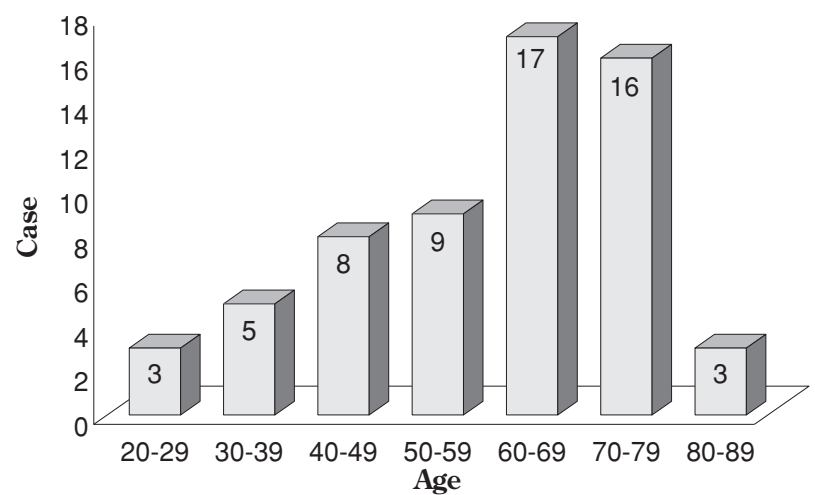

Fig. 1 Age distribution was demonstrated a peak at sixty

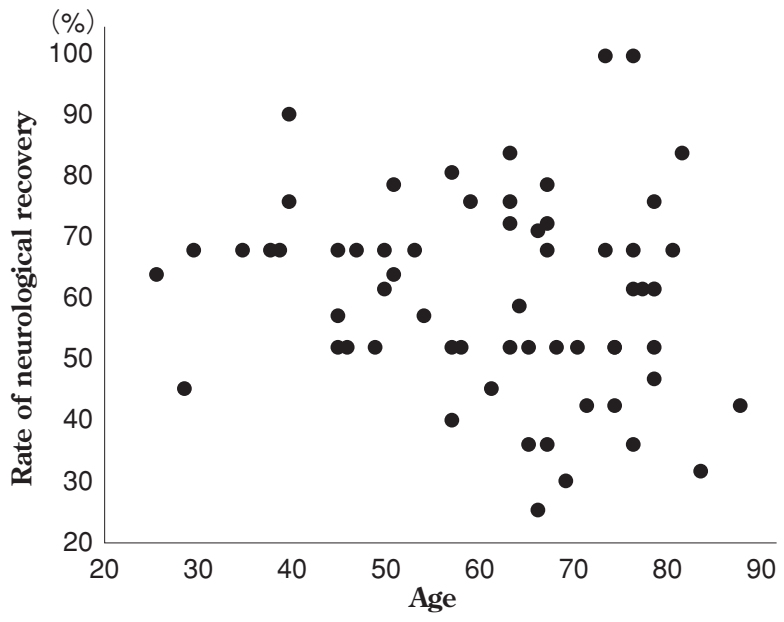

Fig. 2 Correlation between age and neurological recovery rate by NCSS. No correlation was demonstrated
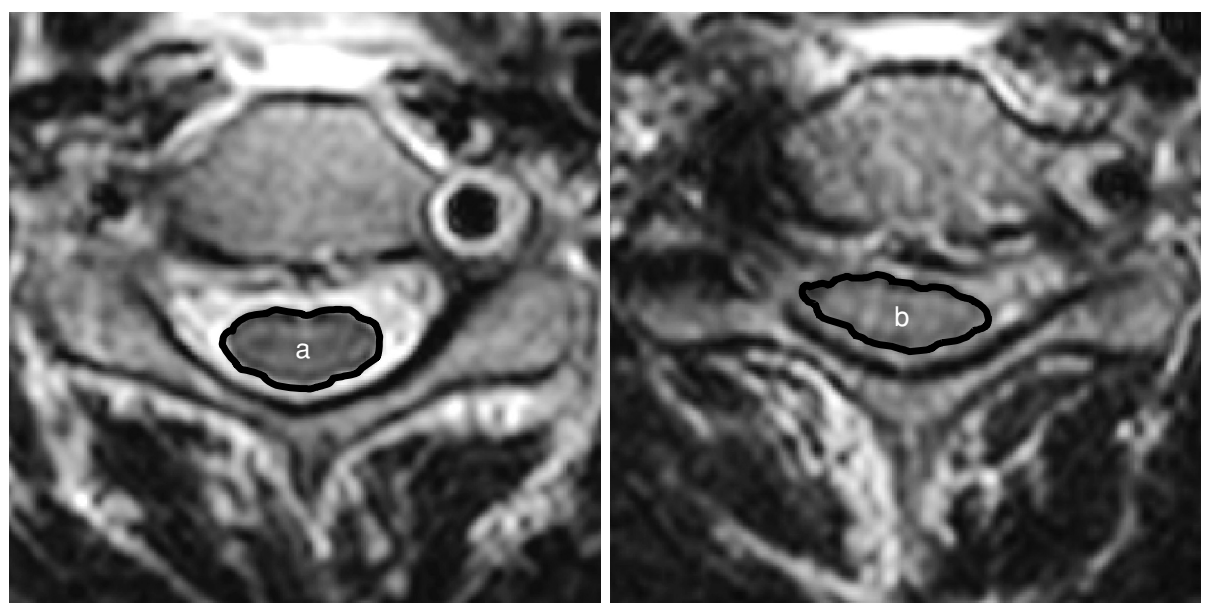

Fig. 3 Compression rate of spinal cord was calculated on axial images (CT or MRI) at the most severe compressed level (b) and an adjacent level without compression (a)

Compression rate of spinal cord $(\%)=\frac{a-b}{a} \times 100$

めなかったが，両群間での平均改善率は所見あり群で $56.1 \%$, 所見なし群で $63.9 \%$ であり, 所見なしの群での 改善が良い結果ではあったが有意とはいえなかった $(\mathrm{p}=0.083)$.

MRI もしくはCTでの軸位像において脊髄が最も圧 迫されている断面での面積 (b) と圧迫のみられない最も 近いレベルでの断面での面積 (a) を計測して, 春髄変形 率〔 $(\mathrm{a}-\mathrm{b}) / \mathrm{a} \times 100]$ を算出した $($ Fig. 3). 各症例での脊 髄変形率と平均改善率との関連を調べてみたが，一定の 相関は認められなかった（Fig. 4).

入院直後より NASCIS-II に準じたステロイド (ソル・ メドロール)の大量持続静注療法が施行された群 (31 例)
での平均改善率は $60.0 \%$,施行されなかった群 (28 例) 間 での平均改善率は $58.5 \%$ で両群間に有意な差は認めな かった。

保存治療のみにて退院された 44 例と外科治療の追加 を要した 17 例での比較では，保存治療群での平均改善 率が $59.6 \%$ であったのに対し，外科治療の追加群では $57.6 \%$ でり，両群間に有意な差は認められなかった。

外科治療が追加された 17 例では，10 例に後方減圧術 が，7例に前方減圧固定術が行われた。原因疾患の内訳 は，後方手術群では脊柱管狭窄症が 10 例中 7 例と最も 多く，前方手術群では椎間板へルニアが 4 例と最も多 かった。後方手術群での平均改善率は $59.0 \%$ ，前方手術 


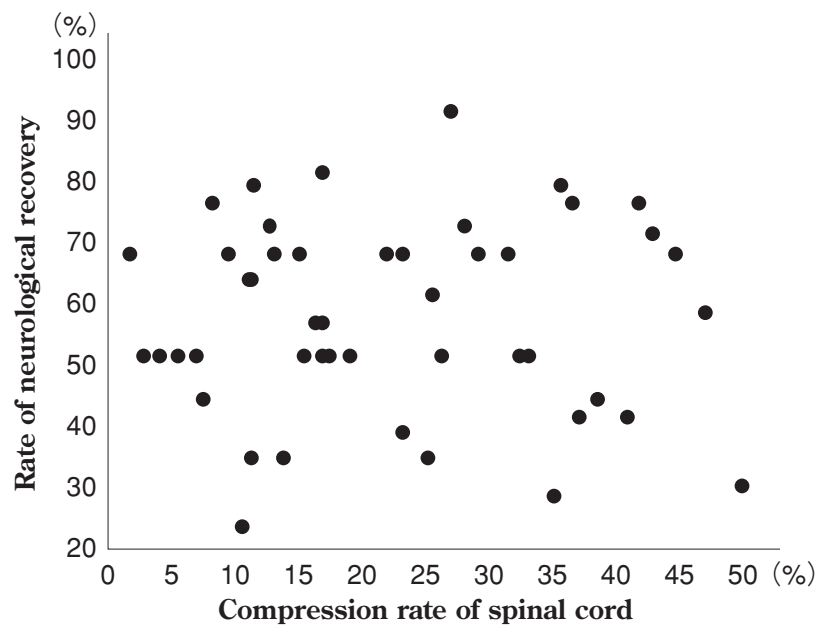

Fig. 4 Correlation between spinal cord compression and neurological recovery rate by NCSS. No correlation was demonstrated

Table 1 Multiple regression analysis demonstrated no correlation between each factors and treatment outcome

\begin{tabular}{lc}
\hline & $\mathrm{p}$ value \\
\hline Age & 0.1209 \\
Gender & 0.8617 \\
Cause of trauma & 0.8557 \\
Mechanism of trauma & 0.6064 \\
Associated cervical pathology & 0.5996 \\
Neurological seriousness on arrival & 0.3510 \\
Intramedullary high signals on MRI (T2WI) & 0.4096 \\
Compression rate of spinal cord & 0.2824 \\
High-dose administration of steroids & 0.1112 \\
Treatment (surgical or conservative) & 0.9793 \\
\hline
\end{tabular}

群での平均改善率は $55.7 \%$ で, 両群間にて有意な差は認 められなかった。

外科治療の施行時期に関しては, 受傷後平均 4.6 週 （1〜12 週，中央值： 5 週）で手術が行われていた. 4 週 以下に手術が行われた 7 例（早期手術群）と 5 週以上に 手術が行われた 10 例（待機手術群）の 2 群に分けて平 均改善率を比較してみたが, 早期手術群では $64.6 \%$, 待 機手術群では $52.8 \%$ であり, 早期手術群の治療成績が良 好ではあったが有意差は認められなかった。各症例にお いて受傷から手術までの期間と平均改善率の関連につい て検討してみたが，一定の相関は認められなかった

(Fig. 5).

以上の各要因に関して重回帰分析を利用した多変量解 析を施行したが，治療成績に有意に影響を与える要因は 認められなかった（Table 1).

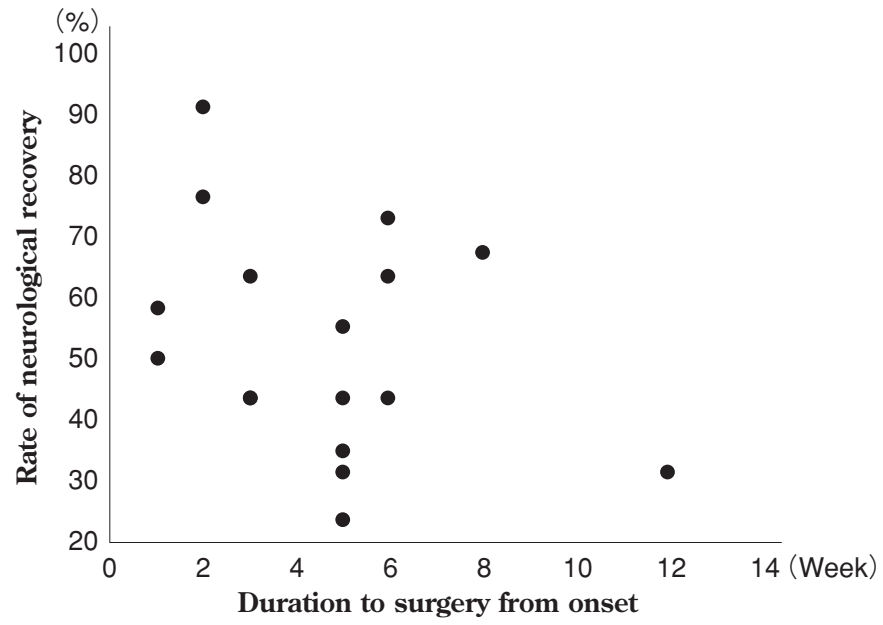

Fig. 5 Correlation between surgical timing and neurological recovery rate by NCSS. No correlation was demonstrated

\section{考 察}

中心性脊髄損傷は, 1954 年に Schneider らによって最 初に報告され ${ }^{1)}$, 最も多く認められる不完全脊髄損傷と されている。ほとんどは，䅡椎の過伸展により発生し， 下肢に比較して上肢の末梢に強い感覚障害，しびれ，巧 緻運動障害を認める。本症の予後は比較的良好であると され，実際われわれの症例でも全例でなんらかの神経症 状の改善が得られているが，症状が完全に回復したのは 2 例 $(3.3 \%)$ にすぎず，ほとんどの症例でなんらかの症 状の残存を認めた。下肢の症状が完全に回復した症例で も, 上肢, 特に手のしびれ, 感覚障害, 巧緻運動障害が 残存する例が多かった，上肢の症状が強いのは春髄視床 路内の神経走行の分布 (lamination) によるといわれ²), 下肢症状は上肢症状よりも改善しやすい3)とされてい る。今回の結果からも運動機能のみの評価ではあるが, 下肢での NCSS 平均改善率 $74.8 \%$ は上肢での $59.4 \%$ を 有意に上回っていた。近年の研究によれば laminationの 存在には疑問がある ${ }^{4,5)}$ との報告もあるが, 多くの症例で 上肢の症状, 特に手の機能障害は残存しやすいといえる.

本症の治療成績に関係する因子として，過去の報告に おいては年齢, 脊柱管前後径, 損傷型 (上肢型, 四肢型), MRI での T2 強調像における髄内の高信号，原因疾患な どが治療成績に関係するとされ，高齢，脊柱管狭小，四 肢型の損傷，MRI での T2 強調像における髄内の高信号 あり，OPLL の存在などが治療成績を悪化させる因子で ある6,7) ともいわれているが, 今回のわれわれの単変量解 析の結果からは性別（男性が良好），受傷原因（交通事故 群が転落群よりも良好)のみが治療成績に影響を与えた。 
性別による成績の違いの原因について検討を加えてみた が，明らかな理由は見いだせなかった。しかし，受傷原 因に関しては, 転落による外力の大きさが脊髄損傷の程 度に関与している可能性が示唆される。

治療に関しては保存治療が推奨されることが多く, 実 際, 最初に報告した Schneider らも自験例での外科治療 群の成績不良を理由に, 本症に対する外科治療は禁忌で ある1) と報告している。最近の報告においても, 非骨傷 性澒髄損傷例における麻瘇の回復について外科治療群と 保存治療群間での成績には有意な差は認めなかったとす るものがあるが8), 本症以外の病態をも含んだ非骨傷性 頝髄損傷すべてを対象とした報告であり，また治療によ る麻瘏の改善のみに着目したものである. 本症において は保存治療にて麻瘦が改善しても手指の感覚障害, しび れ，疼痛などが残存する場合が多く，その評価には注意 が必要と考える。

近年, 本症を含めた不完全䅡髄損傷に対する積極的な 外科治療の施行に関しては肯定的意見も増加してきてい る. Saruhashi らは症状がプラトーに達し, 脊髄圧迫所見 のあるものは手術すべき9) と報告し, 山田らは MRIにて 脊髄の圧迫所見を認める場合や䅡椎の動態撮影で不安定 性のあるものは手術すべきである ${ }^{10)}$ と報告している。わ れわれも過去に非骨傷性䅡髄損傷例に対する治療成績を 報告しているが，その中で本症（中心性澒髄損傷）のみ に関しては外科治療群の成績が保存治療群の成績を上回 る結果であった ${ }^{11)}$. 以上より, われわれの施設では澒椎 に不安定性を有する場合, もしくは春柱管内に脊髄の圧 迫性病変を有する症例で脊髄症状が残存している場合に は, 二次性の脊髄損傷を防ぐ意味からも積極的に外科治 療の適応としている。

今回のわれわれの検討結果から, 外科治療の施行を要 した 17 例での NCSS 平均改善率は $57.6 \%$ であり, 保存 治療のみにて退院された 44 例での $59.6 \%$ との比較では 統計学的には有意差は認められなかった。このことから 保存治療のみの群と外科治療が追加施行された群での治 療成績が同等であるという判断するのは問題がある。入 院時の NCSS 平均総点数を比較してみると保存治療群 では 7.5 であるのに対して, 外科治療群では 6.5 であり, 外科治療群の神経症状が重症であることがわかる.また, 外科治療群での手術直前までの平均改善率は $37.3 \%$ で, 退院時の平均改善率 $57.6 \%$ と比較すれば有意に術後の 改善率が高く $(\mathrm{p}=0.0001)$, 外科治療を行った症例では 術前と比較すれば明らかに術後の神経症状の改善が良い 結果であった。保存治療と外科治療の結果が同等である という解釈ではなく, 外科治療を行うことにより保存治
療のみにて退院した症例と同等の治療成績が得られたと 理解すべきで，外科治療の有用性を強調したい.

一方，外科治療の施行時期に関しても一定の見解はな い. 近年は可及的早期の外科治療を推奨する意見も多く, Guest らは，早期手術（24 時間以内）例は待機手術（24 時間以降) 例よりも ICU 入室期間および入院期間の短縮 化が可能で経済的にも有用性が高い12) と報告している.

Mirza らは，早期手術（72 時間以内）は待機手術（10 14 日後) よりも合併症の発生を高めることなく, 神経症 状を悪化させることもなく, 離床を早め, 神経症状の回 復を促す ${ }^{13)}$ と報告している。鈴木らは早期手術が有害で あるという明らかな証拠はない(14) と報告し, 平野らは自 験例を提示して早期離床を図るという目的から，可能な らば早期に外科治療を行ったほうが有利である ${ }^{15)}$ と早期 手術の有用性を報告している.今回のわれわれの検討で は，受傷後間もない時期での外科治療の施行例はほとん ど存在せず，超急性期での治療成績の有用性は証明でき なかったが, 受傷後 4 週以内に施行された 7 例での平均 改善率 $(64.6 \%)$ は受傷後 5 週以降に施行された 10 例で の平均改善率 $(52.8 \%)$ を上回っており, 今後の症例の 蓄積によっては早期手術の有用性が統計学的に証明され る可能性はある。ただ，受傷後間もない時期での減圧術 の施行後に脊䯣の浮腫による神経症状の悪化を経験する こともあるために，外科治療のタイミングの判断には注 意が必要と考える。

\section{結 語}

中心性䅡髄損傷 61 例の治療成績を報告した。退院時 における NCSS 平均改善率は $59.1 \%$ であり，全例でなん らかの神経症状の改善が得られたが, 症状が完全に消失 したのは 2 例のみで大半の症例では症状が残存した。下 肢に比べて上肢の運動機能障害が強く, 症状の改善も下 肢のほうが良好であった。外科治療を行うことにより保 存治療のみにて退院した症例と同等の治療成績が得られ たものの, 手術時期と治療成績の間に相関は認められな かった.

\section{文 献}

1) Schneider RC, Cherry G, Pantek H: The syndrome of acute central cervical cord injury ; with special reference to the mechanisms involved in hyperextension injuries of cervical spine. J Neurosurg $11: 546-577,1954$

2) Forester $0:$ Symptomatologie der Erkrankungen des Ruckenmarks und seiner Wurzeln. Handb Neurol 5: 104-403, 1936 
3）須田浩太：中心性頚髄損傷の手術治療. 脊椎脊髄 21：611-615, 2008

4) Nathan PW, Smith MC : Long descending tracts in man. 1 Review of present knowledge. Brain 78:248-304, 1955

5) Quencer RM, Bunge RP, Egnor M, et al : Acute traumatic central cord syndrome:MRI-pathological correlations. Neuroradiology $34: 85-94,1992$

6）貴船雅夫, 三村 寛, 酒井和裕, 他：非骨傷性䅡髄損傷 の治療成績に影響を与える因子について，中部整災誌 $44: 379-380,2001$

7）貴船雅夫：中心性澒髄損傷の治療成績に影響を与える 因子について．日パラ医会誌 14:92-93，2001

8）植田尊善, 河野 修：非骨傷性頝損に対する急性期除圧 術の結果. 他施設前向き無作為共同研究の結果. 臨整 外 41:467-472, 2006

9) Saruhashi Y, Hukuda S, Katuura A, et al : Clinical outcomes of cervical spinal cord injuries without radiographic evidence of trauma. Spinal Cord 36:567-573,
1998

10）山田隆壽, 水野順一, 中川 洋 : 骨傷の明らかでない中 心性䅡髄損傷に対する外科的治療. 脊髄外科 $15: 29$ 34,2001

11）安斉公雄，妹尾 誠，堀田隆史，他：骨傷を認めない頚 髄損傷患者に対する頚椎椎弓形成術の治療成績. 脊髄外 科 $17: 7-14,2003$

12) Guest J, Eleraky MA, Apostolides PJ, et al : Traumatic central cord syndrome : results of surgical management. J Neurosurg (1 Suppl) 97:25-32, 2002

13) Mirza SK, Krengel WF, Chapman JR, et al : Early versus delayed surgery for acute cervical spinal cord injury. Clin Orthop 359: 104-114, 1999

14）鈴木晋介，宇都宮昭裕，遠藤俊毅，他：脊椎·春䯣損傷 の急性期治療とその問題点 (1). 脳外速報 $19: 305^{-}$ 312, 2009

15）平野仁崇，伊藤康信，菅原 卓，他：骨損傷のない頚䯣 損傷に対する手術例の検討. 春髄外科 $17: 15-22$, 2003 